\title{
Numerical Simulation of Copper Indium Gallium Diselenide Solar Cells Using One Dimensional SCAPS Software
}

\author{
C. O. Lawani ${ }^{\mathrm{a}}$, G. J. Ibeh ${ }^{\mathrm{a}}$, O. O. Ige ${ }^{\mathrm{a}}$, D. Eli ${ }^{\mathrm{a}, \mathrm{b}, *}$, J. O. Emmanuel ${ }^{\mathrm{a}, \mathrm{c}}$, A. J. Ukwenya ${ }^{\mathrm{a}}$, P. O. Oyedare ${ }^{\mathrm{d}}$ \\ ${ }^{a}$ Department of Physics, Nigerian Defence Academy, Kaduna, Nigeria \\ ${ }^{b}$ Department of Physical Sciences, Greenfield University, Kasarami, Kaduna, Nigeria \\ ${ }^{c}$ Department of Basic Science and General Studies, Federal College of Forestry Mechanization, Kaduna, Nigeria \\ ${ }^{d}$ Department of Science Laboratory Technology, Federal Polytechnic Ede, Osun State, Nigeria
}

\begin{abstract}
The effect of multivalent defect density, thickness of absorber and buffer layer thickness on the performance of CIGS solar cells were investigated systematically. The study was carried out using Solar Cells Capacitance Simulator (SCAPS) code, which is capable of solving the basic semiconductor equations. Employing numerical modelling, a solar cell with the structure $A l|Z n O: A l| \operatorname{In}_{2} S_{3}|C I G S| P t$ was simulated and in it, a double acceptor defect $(-2 /-1 / 0)$ with a density of $10^{14} \mathrm{~cm}^{-3}$ was set in the absorber in the first instance. This initial device gave a power conversion efficiency (PCE) of $25.85 \%$, short circuit current density (Jsc) of $37.9576 \mathrm{mAcm}^{-2}$, Photovoltage (Voc) of $0.7992 \mathrm{~V}$ and fill factor (FF) of 85.22 $\%$. When the density of multivalent defect $(-2 /-1 / 0)$ was varied between $10^{10} \mathrm{~cm}^{-3}$ and $10^{17} \mathrm{~cm}^{-3}$ the solar cells performance dropped from 26.81 $\%$ to $16.87 \%$. The champion device was with multivalent defect of $10^{10} \mathrm{~cm}^{-3}$ which shows an enhancement of $3.71 \%$ from the pristine device. On varying the CIGS layer thickness from $0.4 \mu \mathrm{m}$ to $3.6 \mu \mathrm{m}$, an increase in PCE was observed from $0.4 \mu \mathrm{m}$ to $1.2 \mu \mathrm{m}$ then the PCE began to decrease beyond a thickness of $1.2 \mu \mathrm{m}$. The best PCE was recorded with thickness of $1.2 \mu \mathrm{m}$ which gave Jsc of $37.7506 \mathrm{mAcm}{ }^{-2}, \mathrm{Voc}$ of 0.8059 $\mathrm{V}, \mathrm{FF}$ of $85.2655 \%$. On varying the $\mathrm{In}_{2} S_{3}$ (buffer) layer thickness from $0.01 \mu \mathrm{m}$ to $0.08 \mu \mathrm{m}$, we observed that there was no significant change in photovoltaic parameters of the solar cells as buffer layer thickness increased.
\end{abstract}

DOI:10.46481/jnsps.2021.133

Keywords: SCAPs, CIGS, Multivalent defect, buffer layer, absorber

Article History :

Received: 30 August 2020

Received in revised form: 02 February 2021

Accepted for publication: 04 February 2021

Published: 29 May 2021

(C)2021 Journal of the Nigerian Society of Physical Sciences. All rights reserved. Communicated by: T. Owolabi \& B. J. Falaye

\section{Introduction}

CIGS is a quaternary compound semiconductor which is an alloy of $\mathrm{CuInSe}_{2}$ (CIS) and $\mathrm{CuGaSe} e_{2}$ (CGS) and comprises four elements namely: Copper, Indium, Gallium and Selenium. It is a direct band gap material [1] whose energy band gap could be varied from $1.06 \mathrm{eV}-1.70 \mathrm{eV}$ by changing the Indium to

${ }^{*}$ Corresponding author tel. no: +2348063307256

Email address: danladielibako@gmail .com (D. Eli)
Gallium ratio [2]. According to Hamanche [3], CIGS is the most promising candidate for efficient and low-cost solar cells based on the advantages of the optical and electrical properties of the material [3]. In spite of these attractive features of CIGS material, there are factors which could affect the performance of solar cells whose absorbers are made from this material. Such factors include defect density in semiconductor layers and interfaces of the solar cell, absorber layer and buffer layer thicknesses, bandgap of semiconductor materials, working temperature of the solar cell among others. 
Multivalent defects are defects caused by transition metals which usually occur as impurities or as part of the structure of some semiconductors [4]. Transition metals are metals which have valence electrons in two shells instead of only one. They therefore exhibit multiple oxidation states and can transit from one charge state to another by accommodating a variable number of electrons in their d-orbitals. When multivalent elements occur as impurities in semiconductors, it is not always clear how many of their valence electrons would be used for charge exchange. For example, if tin (Sn) is doped on divalent zinc $(\mathrm{Zn})$ or Magnesium $(\mathrm{Mg})$ site. We are not sure if it will behave as +IV element or a +II element. There is really the possibility that a multivalent impurity would transit from one oxidation state to another and their transition would appear as deep level inside the band gap of the material. Deep levels which are associated with a change in oxidation state tend to deteriorate the electronic properties of semiconductors. As they form recombination centers and carrier traps [4]. We therefore investigate in this work, the effect of multivalent defect density, thickness of absorber and buffer layer on the performance of CIGS solar cells using SCAPS-1D. This software was used to calculate the short circuit current density (Jsc), open circuit voltage (Voc), Fill factor $(\mathrm{FF})$ and efficiency $(\eta)$ which are photovoltaic parameters used for the assessment of solar cells' performance. The spectral response of the solar cells in the face of varying defect density, absorber layer thickness and buffer layer thickness were also studied.

\section{Materials and Methods}

\subsection{Cell Structure}

The solar cells simulated have the structure $A l|\mathrm{ZnO}: A l| \mathrm{In}_{2}$ $S_{3}|C I G S| P t \mid$ as shown in figure1. The main parts of the cells are CIGS absorber and the $\operatorname{In}_{2} S_{3}$ buffer layers. The CIGS absorber is responsible for trapping light from the sun. It is considered environmental friendly because of the absence of Cadmium in its structure. The material has a direct band gap and high absorption coefficient requiring just a few micrometers to absorb the maximum incident photon. The wide band gap of this material has also been found to be variable depending on the composition of the CIGS material [5]. The $\operatorname{In}_{2} S_{3}$ is chosen as the buffer since it is stable, has a wider band gap and is considered nontoxic, when compared with other buffers such as CdS. It is also transparent and photoconductive [6]. A transparent conductive Oxide (TCO) layer (acting as the window) made of $\mathrm{ZnO}: \mathrm{Al}$ is deposited on top of the buffer layer as it is transparent to most of the solar spectrum because of its wide band gap.Although $\mathrm{ZnO}$ :B (Boron doped Zinc Oxide) could be more beneficial for the solar cells because it lowers absorption losses leading to an increase in the quantum efficiency of the solar cells[7], $\mathrm{ZnO}: \mathrm{Al}$ is used in this research because it is a low cost TCO and it is also highly conductive. Front and back contacts usually made of metallic elements are introduced in the cells' structure for the conduction of photogenerated charge carriers in and out of the solar cells. Al is used as the front contact in this work, because it is lightweight, non-magnetic and corrosion resistant. It is a good conductor of electricity; more conductive

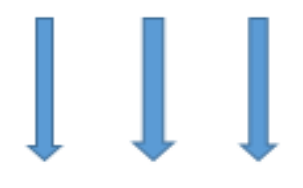

Direction of incident light

\begin{tabular}{|l|l|}
\hline Front_contact & Al \\
\hline Window_layer & $\underline{\text { ZnO: Al }}$ \\
\hline Buffer & $\mathrm{In}_{2} \mathrm{~S}_{3}$ \\
\hline Absorber & CIGS \\
\hline Back_contact & Pt \\
\hline
\end{tabular}

Figure 1. Model of the simulated solar cell.

than Copper and less expensive than silver. A back contact of $\mathrm{Pt}$ is preferred to the commonly used Molybdenum since it is nontoxic when compared with Molybdenum and gives a cell with higher efficiency [8].

\subsection{Numerical Modelling}

The method used for this work is numerical simulation. $\mathrm{Nu}-$ merical simulation often gives insight into the interpretation of measurements even as it aids in the assessment of the potential merits of a cell structure [7]. Some softwares among which is SCAPS-1D can be used to analyze the effect of the variation of materials parameters, that is, the presence or absence of particular properties or the varying of all properties in the range of values, for the optimization of solar cells' efficiencies. This helps the producers of solar cells with the needed insight to effect necessary changes in their production methods in order to improve product performance. SCAPS- 1D simulation results have a good agreement with the results of existing experimental works [9] and this is the major motivating factor for its use in this research. SCAPS computes the steady state band diagram, recombination profile and carrier transport in one dimension, based on Poisson's equation (equation 1) together with the continuity equations (equations $2 \mathrm{a}$ and $2 \mathrm{~b}$ ) for holes and electrons.

$$
\begin{aligned}
& \nabla \cdot \epsilon E=q(p-n+N) \\
& \frac{\partial n(x, t)}{\partial t}=\frac{1}{q} \frac{\partial J_{n}}{\partial x}+G_{n}(x, t)-R_{n}(x, t) \\
& \frac{\partial p(x, t)}{\partial t}=\frac{1}{q} \frac{\partial J_{p}}{\partial x}+G_{p}(x, t)-R_{p}(x, t)
\end{aligned}
$$

where $E=$ electric field; $\epsilon=$ permittivity of semiconductor; $q$ = electronic charge; $n=$ concentration of electrons; $p=$ concentration of holes; $N=$ net charge due to dopants and other trapped charges; $J n$ and $J p=$ current density of electrons and holes; $G n$ and $G p=$ rates of electron and holes generation in 


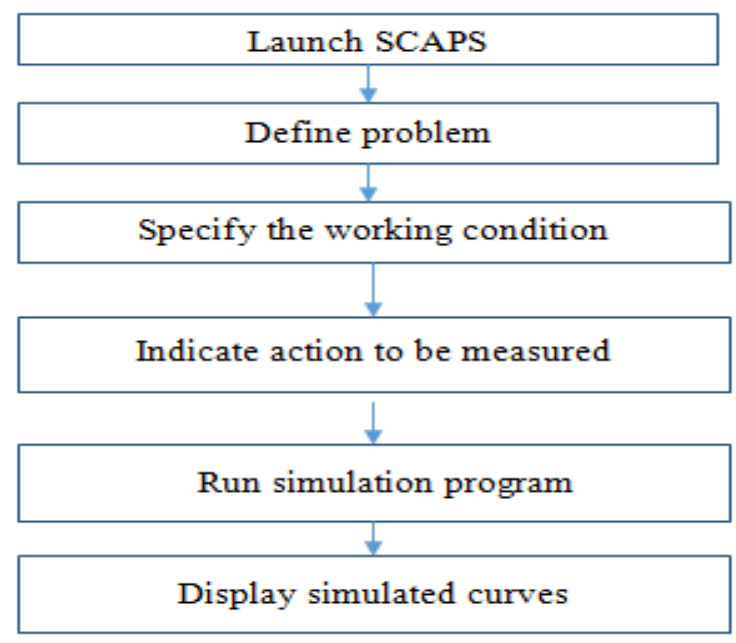

Figure 2. Simulation procedure.

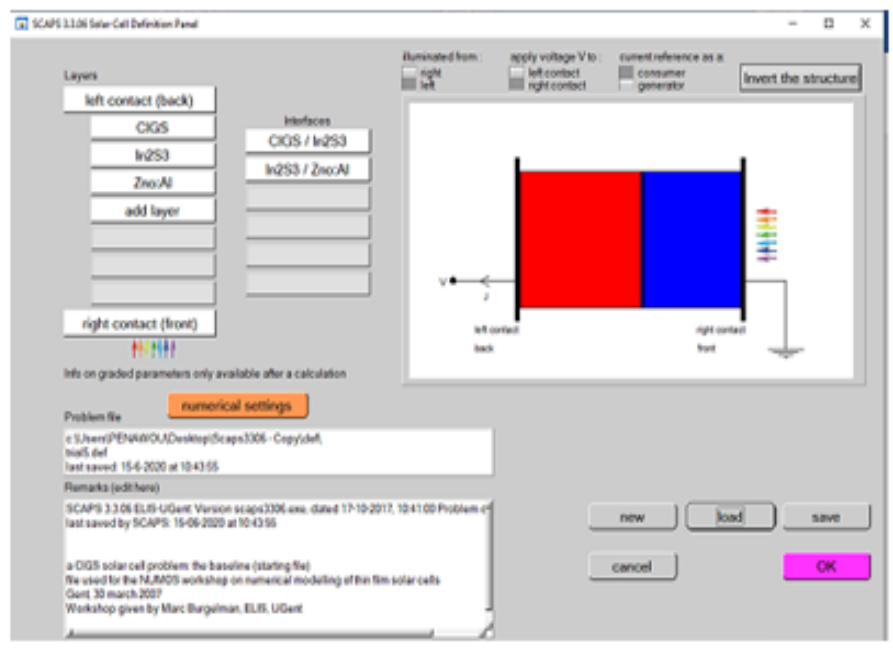

Figure 3. SCAPS solar cell definition panel.

the semiconductor device; $R n$ and $R p$ are rates of electron and hole recombination in the solar cells.

Figure 2 shows the steps that were taken in the simulation, starting with the launch of SCAPS.

\subsection{Simulated Parameters}

The material parameters were selected from experimental results $[10,11,12]$. Table1 gives a summary of the parameters for each layer in the simulation. Defect parameters in the layers and interfaces were sourced from literatures $[1,13,14,15]$ as shown in table 2. The work functions of the front contact (Al) and back contact $(\mathrm{Pt})$ are $4.26 \mathrm{eV}$ and $5.93 \mathrm{eV}$, respectively [16]. A working temperature of $300 \mathrm{~K}$, solar spectrum AM1.5 and a Scanning voltage of $0 \mathrm{~V}-1.3 \mathrm{~V}$ were used for all simulations.

The solar cell definition panel shown in figure 3 is the environment where the physical properties of the various layers of the solar cells were inputted.

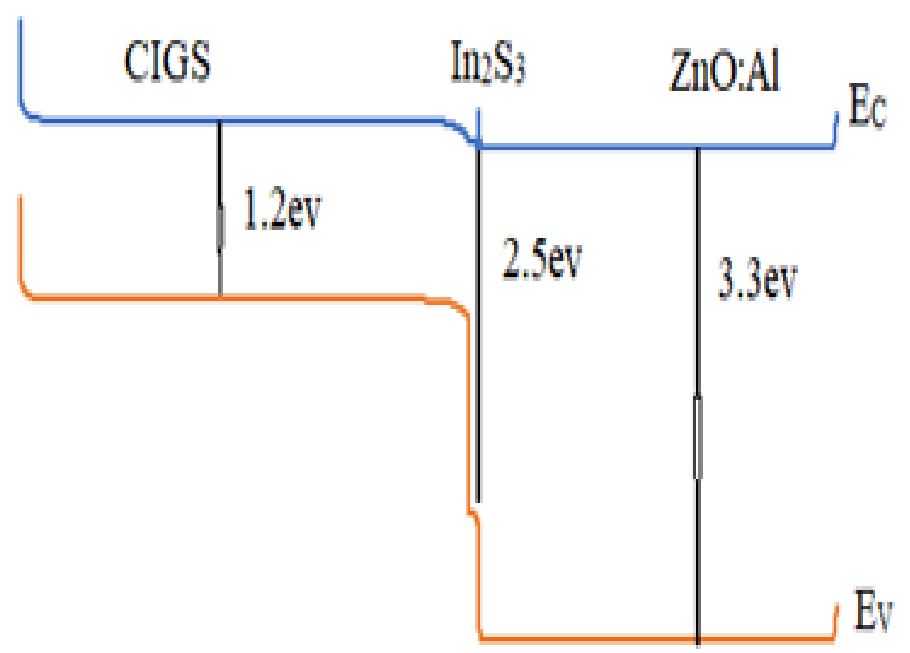

Figure 4. Energy band diagram in the CIGS solar cell.

\section{Results and Discussion}

\subsection{Performance parameters from initial simulation}

In the initial device set up for this work, a multivalent defect in the form of a double acceptor $(-2 /-1 / 0)$ defect with a Gaussian energy distribution, defect energy level $(E t)=\{0.1,0.4\} \mathrm{eV}$ above $E_{v}$ and a concentration of $1.0 \times 10^{14} \mathrm{~cm}^{-3}$, was introduced into the CIGS (absorber) layer. This defect which is mainly caused by $C u_{I I I}\left(C u_{I I I}\right.$ is a double acceptor and III represents a group 3 element such as Indium or Gallium) defect is common in CIGS absorbers [17]. Details of other defects set in the simulation are given in Table 2; the resulting performance parameters of the open- circuit voltage $\left(V_{O C}\right)$, short- circuit current density $\left(J_{S C}\right)$, fill factor $(\mathrm{FF})$ and efficiency determined using $\mathrm{J}$ $\mathrm{V}$ characteristics are compared with those derived from experimental work [18]. The comparison which is shown in Table 3 reveals that there is a good agreement between data from calculations and those from experiment hence validating parameters used in the simulation. The J-V curve and quantum efficiency curve are also obtained and shown below. The parameters of the different layers used in the simulation are also given in Table 1.

In the quantum efficiency (spectral response) curve shown in Figure 6, there is an observed increase of spectral response in the short wavelength between $350 \mathrm{~nm}(0.35 \mu \mathrm{m})$ and $400 \mathrm{~nm}(0.4 \mu \mathrm{m})$. The curve reveals a maximum efficiency of approximately 100 $\%$ occurring between $400 \mathrm{~nm}(0.4 \mu \mathrm{m})$ and $1000 \mathrm{~nm}(1 \mu \mathrm{m})$ but this high efficiency begins to fall off after $1000 \mathrm{~nm}(1 \mu \mathrm{m})$. This fall is very likely due to incomplete absorption of the long wavelength photons. This analysis pertaining to the quantum efficiency, agrees very much with those reported in literatures $[1,19]$.

\subsection{Effect of multivalent defect concentration in CIGS (ab- sorber) layer}

The density of absorber layer defect has a direct effect on photovoltaic cell performance because as the concentration of 
Table 1. Materials parameters for $C I G S\left|I_{2} S_{3}\right| Z n O: A l \mid$ solar cell [10,11,12].

\begin{tabular}{lccc}
\hline Layer parameter & CIGS & $\mathrm{In}_{2} \mathrm{~S}_{3}$ & $\mathrm{ZnO}: \mathrm{Al}$ \\
\hline Thickness $(\mu \mathrm{m})$ & 2 & 0.04 & 1.6 \\
Band gap, $E_{g}(\mathrm{eV})$ & 1.2 & 2.5 & 3.3 \\
Electron affinity, $\chi_{e}(\mathrm{eV})$ & 4.25 & 4.25 & 4.6 \\
Relative permitivity $\epsilon_{e}$ & 13.6 & 13.5 & 9 \\
$N_{c}$, effective density of states $\left(1 / \mathrm{cm}^{3}\right)$ & $2.2 \times 10^{18}$ & $1.8 \times 10^{19}$ & $2.2 \times 10^{18}$ \\
$N_{v}$, effective density of states $\left(1 / \mathrm{cm}^{3}\right)$ & $1.8 \times 10^{19}$ & $4.0 \times 10^{13}$ & $1.8 \times 10^{19}$ \\
Electron mobility, $\mu_{n}\left(\mathrm{~cm}^{2} / V_{s}\right.$ & 100 & 400 & 100 \\
Hole mobility, $\mu_{p}\left(\mathrm{~cm}^{2} / V_{s}\right.$ & 25 & 210 & 25 \\
Acceptor concentration $N_{A}\left(1 / \mathrm{cm}^{3}\right)$ & $1.0 \times 10^{16}$ & 0 & 0 \\
Donor concentration $N_{D}\left(1 / \mathrm{cm}^{3}\right)$ & 0 & $1.0 \times 10^{18}$ & $1.0 \times 10^{18}$ \\
\hline
\end{tabular}

Table 2. Defect parameters of buffer, window and interfaces $[1,13,14,15]$.

\begin{tabular}{lcccc}
\hline Parameters & $\mathrm{In}_{2} S_{3}$ & $\mathrm{ZnO}: \mathrm{Al}$ & $\begin{array}{c}\mathrm{CIGS} / \mathrm{In}_{2} \mathrm{~S}_{3} \\
\text { Interface }\end{array}$ & $\begin{array}{c}\mathrm{In}_{2} \mathrm{~S}_{3} / \mathrm{ZnO}: \mathrm{Al} \\
\text { Interface }\end{array}$ \\
\hline Defect Type & Acceptor & 0.04 & 1.6 & \\
Capture cross section for electrons $\sigma_{n}\left(\mathrm{~cm}^{2}\right)$ & $1.0 \times 10^{-15}$ & $1.0 \times 10^{-12}$ & $1.0 \times 10^{-14}$ & $1.0 \times 10^{-12}$ \\
Capture cross section for holes $\sigma_{h}\left(\mathrm{~cm}^{2}\right)$ & $5.0 \times 10^{-13}$ & $1.0 \times 10^{-12}$ & $1.0 \times 10^{-14}$ & $1.0 \times 10^{-15}$ \\
Energetic Distribution & Gaussian & Gaussian & Single & Single \\
Energy level with respect to reference (eV) & 0.6 above $E_{v}$ & 0.6 above $E_{v}$ & 0.6 above $E_{v}$ & 0.6 above $E_{v}$ \\
Characteristic Energy level (eV) & 0.1 & 0.1 & 0.1 & 0.1 \\
Total density $\left(\mathrm{cm}^{-3}\right)$ & $1.0 \times 10^{14}$ & $1.772 \times 10^{16}$ & & \\
Concentration $\left(\mathrm{cm}^{-2}\right)$ & & & $1.0 \times 10^{10}$ & $1.0 \times 10^{10}$ \\
\hline
\end{tabular}

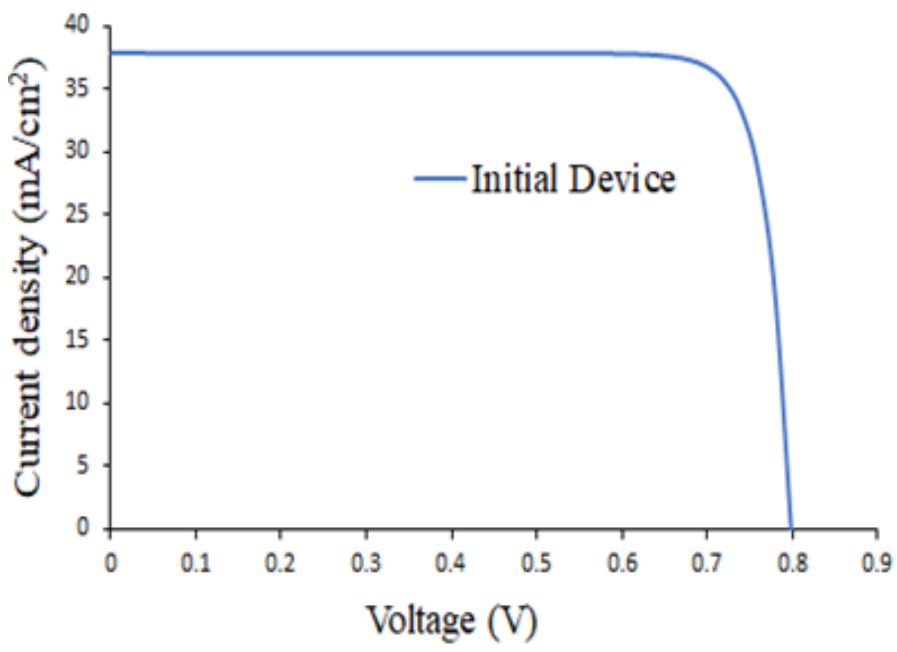

Figure 5. J-V curve of CIGS solar cell with initial parameters.

defects increase, the minority charge lifetime reduces. This is evident from

$$
\tau=\frac{1}{\sigma V_{t h} N_{t}}
$$

Equation 3 above where $\tau$ is the minority charge lifetime, $\sigma$ is electron/hole capture cross section, $V_{t h}$ is thermal velocity of electron/holes and $N_{t}$ is total density of defects but $\sigma V_{t h}=c$ and $c$ is the capture constant of electron/holes so $\tau=\frac{1}{c N_{t}}$ meaning that the life time $\tau$ is inversely proportional to the product of defect density and capture constant of the charge carrier. With
Table 3. Results from initial simulation compared with experimental data.

\begin{tabular}{lcccc}
\hline & $\begin{array}{c}V_{O C} \\
(V)\end{array}$ & $\begin{array}{c}J_{S C} \\
\left(\mathrm{~mA} / \mathrm{cm}^{2}\right)\end{array}$ & $\begin{array}{c}\text { FF } \\
(\%)\end{array}$ & $\begin{array}{c}\text { Efficiency } \\
(\%)\end{array}$ \\
\hline Experimental [18] & 0.7410 & 37.8000 & 80.60 & 22.60 \\
Simulation & 0.7992 & 37.9576 & 85.22 & 25.85 \\
\hline
\end{tabular}

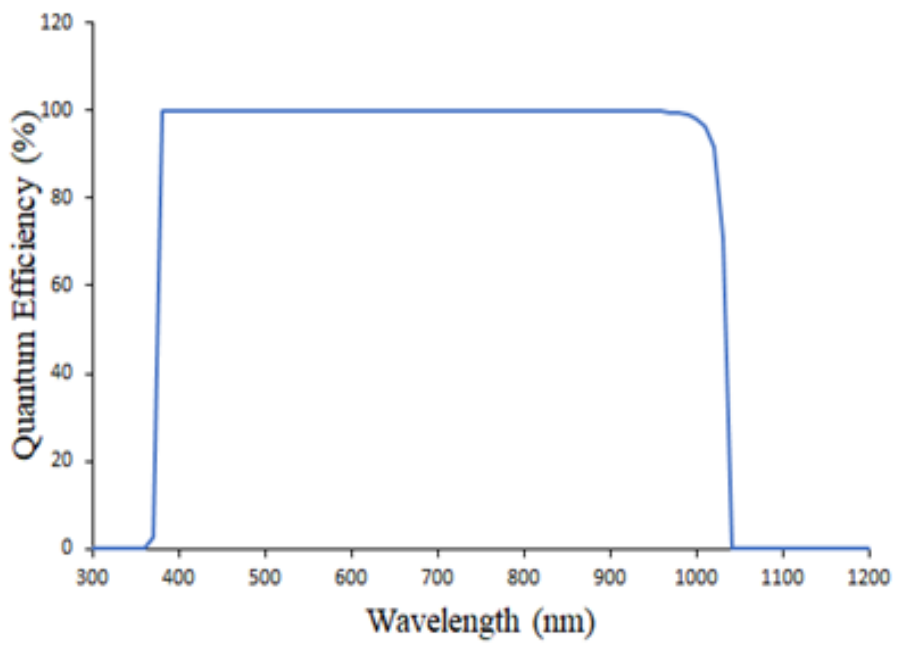

Figure 6. Quantum efficiency curve with initial parameters.

reduction in life time, the diffusion length of electrons and holes reduces. Diffusion length is the average distance a charge carrier can travel in a semiconductor material before it recombines.

$$
\text { Diffusion length, } L=\sqrt{D_{\tau}}
$$


meaning that if defect density increases, $\tau$ reduces and diffusion length reduces also. In Equation 4, D is the diffusion coefficient for electrons/holes With a reduction in diffusion length, the probability of collection of photogenerated charge carriers at the terminals reduces; this in turn lowers the photocurrent for the solar cell, and increase the chances of recombination hence increasing the recombination loss in the absorber [20].

Defects could be introduced either intentionally or unintentionally into semiconductors during the growth process, during processing of the device or from the working environment [21]. Theoretical studies which are confirmed by results of measurement show that most of the existing defects in chalcopyrite solar cells, are multivalent in nature [22, 23]. In this study, the impact of varying multivalent defect concentration is observed by choosing the values of the defect density in the range of $10^{10} \mathrm{~cm}^{-3}-10^{17} \mathrm{~cm}^{-3}$. Table 4 gives the performance parameters of the CIGS solar cells with various values of multivalent defect density in the absorber. It would be observed that the

Table 4. Dependence of cells performance on multivalent defect density in CIGS absorber layer.

\begin{tabular}{lcccc}
\hline $\begin{array}{l}\text { Multivalent } \\
\text { defect } \\
\text { density } \\
\left(\mathrm{cm}^{-3}\right)\end{array}$ & $\begin{array}{c}V_{O C} \\
(V)\end{array}$ & $\begin{array}{c}J_{S C} \\
\left(\mathrm{~mA} / \mathrm{cm}^{2}\right)\end{array}$ & $\begin{array}{c}\mathrm{FF} \\
(\%)\end{array}$ & $\begin{array}{c}\eta \\
(\%)\end{array}$ \\
\hline $10^{10}$ & & & & \\
$10^{11}$ & 0.82086 & 37.96297 & 86.0388 & 26.8116 \\
$10^{12}$ & 0.82083 & 37.96297 & 86.0371 & 26.8102 \\
$10^{13}$ & 0.82059 & 37.96292 & 86.0196 & 26.7967 \\
$10^{14}$ & 0.81785 & 37.96244 & 85.8998 & 26.6700 \\
$10^{15}$ & 0.79924 & 37.95760 & 85.2210 & 25.8537 \\
$10^{16}$ & 0.74993 & 37.90711 & 83.6588 & 23.7824 \\
$10^{17}$ & 0.70338 & 37.29294 & 80.0979 & 21.0106 \\
\hline
\end{tabular}

solar cells' performance does not change much when the defect density is below $10^{14} \mathrm{~cm}^{-3}$. This result tallies with the finding of similar study [24] in this regard. Figure 7 shows that all electrical performance parameters start degrading at a defect density of $\approx 10^{15} \mathrm{~cm}^{-3}$. $V_{O C}$ goes down from $0.82086 \mathrm{~V}$ to $0.67284 \mathrm{~V}$, representing a decrease of $22.38 \%$. $J_{S C}$ falls from $37.96297 \mathrm{~mA} / \mathrm{cm}^{2}$ to $33.33359 \mathrm{~mA} / \mathrm{cm}^{2}$ corresponding to a decrease of $13.89 \%$. These drops may be attributed to recombination within localized energy levels created by defects which cause current leakage [25]. As a result, the conversion efficiency goes down from $26.8116 \%$ to $16.8716 \%$ representing a decrease of $58.92 \%$. Since solar cell efficiency is the amount of energy in the form of sunlight that can be converted into electricity by a solar cell, this $58.92 \%$ decrease in conversion efficiency brought about by an increase in concentration of multivalent defect in the absorber layer poses a disadvantage to the functioning of the solar cell. According to a study [26], an efficient solar cell will have a high short circuit current density $J_{s c}$, a high open circuit $V_{o c}$ and a fill factor as close as possible to 1 (or $100 \%$ ). The fill factor is a measure of the ideality of a solar cell. In Figure 7, the fill factor is observed to depart more from its ideal value of $100 \%$ with an increase in the density of multivalent defect in the absorber leading to less efficiency and ideality of the solar cells.

The multivalent defect density which produces an optimum performance of the solar cells is $10^{10} / \mathrm{cm}^{3}$ at an open circuit voltage $V_{o c}$ of $0.8209 \mathrm{~V}$, short circuit current density $J_{s c}$ of $37.96300 \mathrm{~mA} / \mathrm{cm}^{2}$, fill factor FF of $86.0388 \%$ and conversion efficiency $\eta$ of $26.8116 \%$ (as shown in Figure 8). This implies that multivalent defect densities (double acceptors, in this case) in CIGS solar cells should be controlled in such a way that they do not exceed this value.

Figure 9 shows the quantum efficiency (QE) as a function of wavelength for different values of defect density in the CIGS layer. When the wavelength is in the range of $300 \mathrm{~nm}(0.3 \mu \mathrm{m})$ - $1200 \mathrm{~nm}(1.2 \mu \mathrm{m})$ the absorption efficiency decreases with increased multivalent defect density in the CIGS layer. This is because as defect density increases the recombination (which causes loss of charge carriers) phenomena becomes more pronounced and since quantum efficiency is the ratio of the number of carriers collected by the solar cell to the number of incident photons [19], quantum efficiency drops.

\subsection{Effect of varying $\mathrm{In}_{2} \mathrm{~S}_{3}$ (buffer) layer thickness}

The influence of the thickness of $\operatorname{In}_{2} S_{3}$ buffer layer on performance of the photovoltaic cell is shown in Figure 10. The thickness of the buffer was varied from $0.01 \mu \mathrm{m}$ through $0.08 \mu \mathrm{m}$. Although the variation of all photovoltaic parameters with increasing buffer thickness is not very significant, a reduction in the efficiency of the solar cells with increasing thickness of the buffer was noticed, in line with the findings in literatures [27, $28,29]$. This is caused by absorption of some photons in this layer [27] as a large number of short-wave length photons are absorbed before reaching the absorber layer while photons having wavelengths greater than that associated with the band gap of the buffer cannot generate electron-hole pairs and are therefore lost as heat. Whereas a thin buffer layer means majority of photons can pass through the buffer into the absorber without being absorbed, increasing the buffer layer thickness causes a drop in efficiency of the solar cells. This is due to photon loss occurring inside the buffer layer.

When a smaller number of photons make it through the buffer, less electron-hole pairs are created and this means less electricity is generated. This agrees with the findings [29]. The observed reduction in $J_{S C}$ is caused by less production of electron-hole pair as a smaller number of electron- hole pairs can reach the absorber layer with increase in buffer layer thickness. A decreased short circuit current means that less photogenerated carriers are produced and this lowers the efficiency of the solar cells. Apart from the very little initial decrease in $V_{o c}$ when buffer layer thickness is increased from $0.01 \mu \mathrm{m}$ to $0.02 \mu \mathrm{m}$, the open circuit voltage remains constant showing that the buffer layer thickness has little or no effect on $V_{o c}$. From Figure 10, there is a slight increment in fill factor when buffer layer thickness is increased from $0.02 \mu \mathrm{m}$ to $0.03 \mu \mathrm{m}$ thereafter, FF begins to drop again. These changes must have resulted from valence band discontinuities at the interfaces that appear as spikes [14]. The best efficiency of the solar cells after variation of the buffer thickness is $25.9813 \%$ and this is achieved 

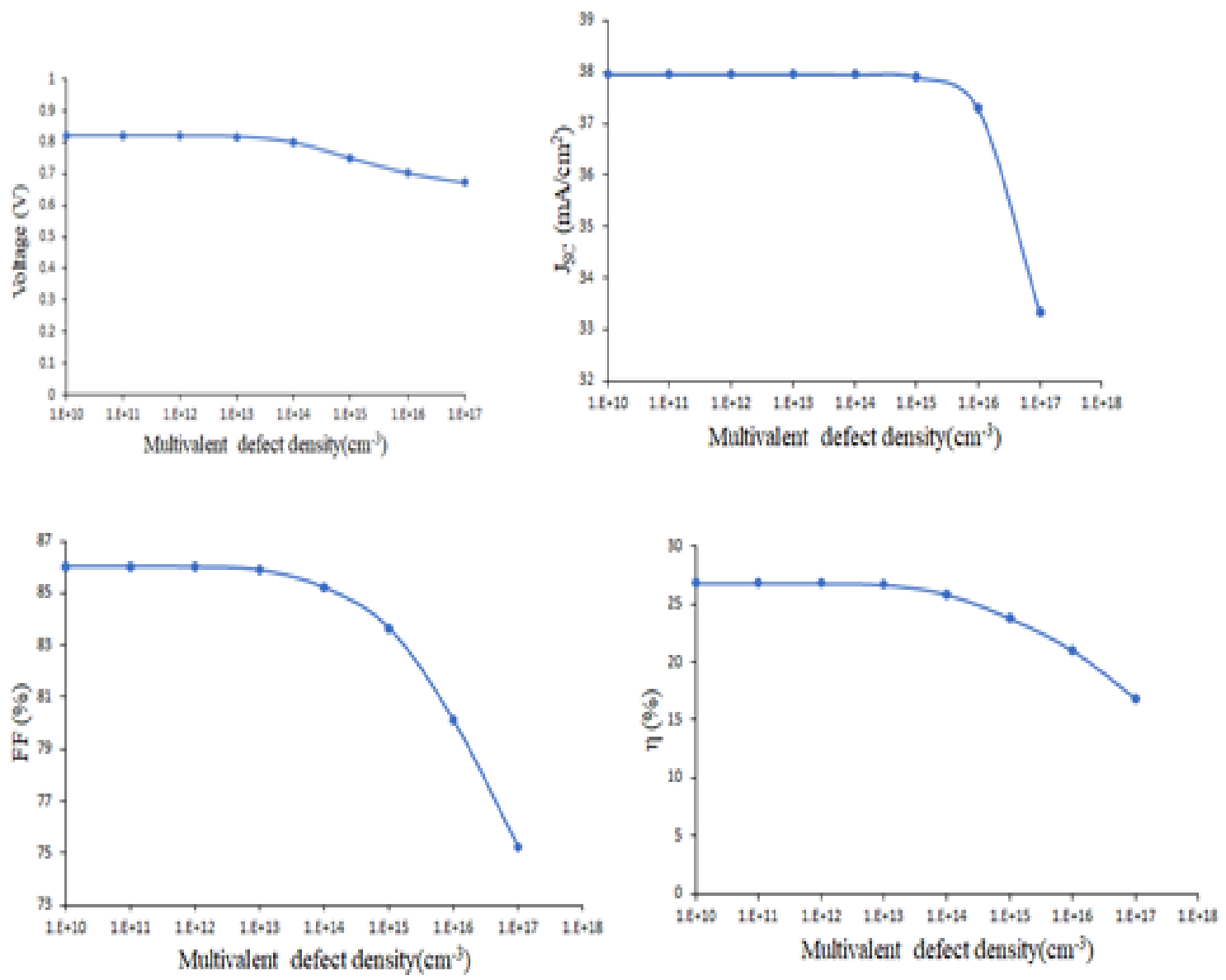

Figure 7. Variation in performance of CIGS solar cells with multivalent defect density.

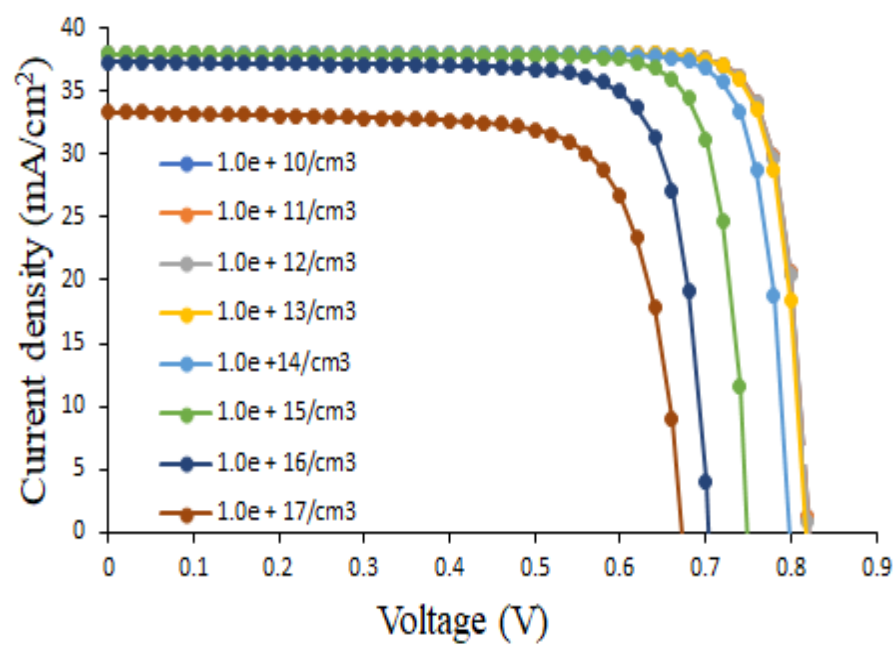

Figure 8. J-V curves of CIGS solar cells with various values of multivalent defect density.

Table 5. Dependence of solar cells' performance on buffer layer thickness.

\begin{tabular}{lcccc}
\hline $\begin{array}{l}\text { Thickness } \\
\text { of buffer } \\
(\mu \mathbf{m})\end{array}$ & $\begin{array}{c}\mathbf{V}_{\mathbf{O C}} \\
(\mathbf{V})\end{array}$ & $\begin{array}{c}\mathbf{J}_{\mathbf{s c}} \\
\left(\mathbf{m A} / \mathbf{c m}^{2}\right)\end{array}$ & $\begin{array}{c}\mathbf{F F} \\
\mathbf{\%}\end{array}$ & $\begin{array}{c}\eta \\
\mathbf{\%}\end{array}$ \\
\hline 0.01 & 0.8030 & 37.9591 & 85.2329 & 25.9813 \\
0.02 & 0.7997 & 37.9586 & 85.2183 & 25.8698 \\
0.03 & 0.7993 & 37.9582 & 85.2211 & 25.8556 \\
0.04 & 0.7992 & 37.9576 & 85.2210 & 25.8537 \\
0.05 & 0.7992 & 37.9569 & 85.2206 & 25.8529 \\
0.06 & 0.7992 & 37.9560 & 85.2202 & 25.8521 \\
0.07 & 0.7992 & 37.9549 & 85.2198 & 25.8512 \\
0.08 & 0.7992 & 37.9536 & 85.2193 & 25.8502 \\
\hline
\end{tabular}

for a thickness of $0.01 \mu m$ at an open circuit voltage $V_{o c}$ of $0.8030 \mathrm{~V}, J_{s c}$ of $37.9591 \mathrm{~mA} / \mathrm{cm}^{2}$ and fill factor of $85.2329 \%$ (as shown in Figure 11).

Figure 12 shows the quantum efficiency (QE) as a function of wavelength for different values of buffer $\left(\operatorname{In}_{2} S_{3}\right)$ layer 


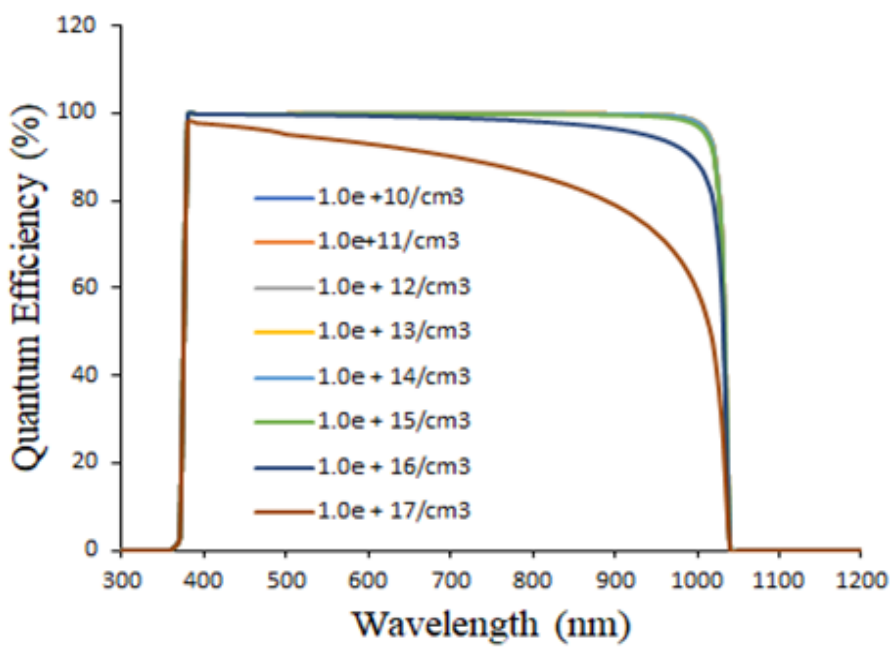

Figure 9. Quantum efficiency as a function of wavelength for different values of defect density in CIGS layer.

thickness. When the wavelength is in the range of $300 \mathrm{~nm}$ $(0.3 \mu \mathrm{m})-1200 \mathrm{~nm}(1.2 \mu \mathrm{m})$, we observed that the spectral response curves overlap because the absorption efficiency remains constant for all values of buffer layer thickness. This spectral response in relation to varying buffer layer thickness further proves that buffer layer thickness has little or no effect on CIGS solar cells investigated.

\subsection{Effect of varying CIGS (absorber) layer thickness}

An important parameter which also affects the performance of CIGS solar cells is the thickness of the absorber layer. The effect of thickness of the absorber layer on the solar cell's performance parameters $V_{O C}, J_{S C}$, FF, PCE is seen in Figure 13. When the thickness of CIGS absorber layer was varied from $0.4 \mu m$ to $3.6 \mu m$, the solar cell's efficiency was seen to increase from $23.96 \%$ to $25.94 \%$ for an increase in thickness, of $0.4 \mu \mathrm{m}$ $-1.2 \mu \mathrm{m}$ respectively. This increase is attributable to absorption of more photons as absorber layer thickness increases. This translates to the production of a significant number of electronhole pairs which then leads to an improvement in efficiency of the solar cells [12]. This is good for the performance of the solar cells since it means that more of the sun's energy would be converted to electricity in the solar cells. Beyond an absorber thickness of $1.2 \mu \mathrm{m}$, the efficiency begins to drop due to decreased collection of photo-generated charge carriers which is caused by charge recombination. This tallies with similar finding [24] $J_{S C}$ increases with increasing absorber thickness since longer wavelength photons are absorbed in thicker layers of the absorber and they enhance the amount of photo-generated carriers which in turn boosts efficiency and therefore produces solar cells which perform better.

Fill factor FF remains nearly constant but $V_{O C}$ kept decreasing as a result of recombination of charge carriers [20] which increases in thicker layers of the absorber. this is not good for the performance of the solar cell as the efficiency of the solar cell has a direct dependence on open circuit voltage Voc. For optimum performance, the absorber thickness of the CIGS solar cells should be kept at $1.2 \mu \mathrm{m}$. The photovoltaic cell parameters corresponding to this optimum value are $V o c$ of $0.8059 \mathrm{~V}, J_{s c}$ of $37.7506 \mathrm{~mA} / \mathrm{cm}^{2}$, FF of $85.2655 \%$ and conversion efficiency of $25.9403 \%$ (as shown in Figure 14).

Table 6. Dependence of solar cells' performance on absorber layer thickness.

\begin{tabular}{lcccc}
$\begin{array}{l}\text { Thickness } \\
\text { of absorber } \\
(\mu \mathbf{m})\end{array}$ & $\begin{array}{c}\mathbf{V}_{\mathbf{O C}} \\
(\mathbf{V})\end{array}$ & $\begin{array}{c}\mathbf{J}_{\text {sc }} \\
\left(\mathbf{m A} / \mathbf{c m}^{\mathbf{2}}\right)\end{array}$ & $\begin{array}{c}\mathbf{F F} \\
\boldsymbol{\%}\end{array}$ & $\begin{array}{c}\eta \\
\%\end{array}$ \\
\hline 0.4 & & & & \\
0.8 & 0.8126 & 34.5688 & 85.2896 & 23.9577 \\
1.2 & 0.8097 & 37.2321 & 85.2886 & 25.7114 \\
1.6 & 0.8059 & 37.7506 & 85.2655 & 25.9403 \\
2.0 & 0.8024 & 37.9045 & 85.2379 & 25.9258 \\
2.4 & 0.7992 & 37.9576 & 85.2210 & 25.8537 \\
2.8 & 0.7961 & 37.9805 & 85.2398 & 25.7724 \\
3.2 & 0.7933 & 37.9930 & 85.2467 & 25.6934 \\
3.6 & 0.7909 & 38.9921 & 85.2450 & 25.6128 \\
\hline
\end{tabular}

Figure 15 shows the quantum efficiency (QE) as a function of wavelength for different values of absorber (CIGS) layer thickness. When the wavelength is in the range of $300 \mathrm{~nm}$ $(0.3 \mu \mathrm{m})-1200 \mathrm{~nm}(1.2 \mu \mathrm{m})$ the absorption efficiency increases with increased absorber (CIGS) layer thickness. This is because as absorber (CIGS) layer thickness increases the number of absorbed photons increases consequently, a higher number of electron-hole pairs are produced and the quantum efficiency increases [1]. For all values of absorber (CIGS) layer thickness, it is observed that the spectral response curves show a decrease of the long wave length collection. This is most likely due to incomplete absorption of the long wavelength photons [30].

\subsection{Performance of optimized parameters}

Based on the optimized multivalent defect density, absorber layer thickness and buffer layer thickness, an efficiency of 27 $\%$, current density of $37.75 \mathrm{~mA} / \mathrm{cm}^{3}$, voltage of $0.829 \mathrm{~V}$ and fill factor of $86.26 \%$ were obtained as depicted in Figure 16. Compared with the experimental data obtained by Jackson et $a l$.[18] were an efficiency of $22.6 \%$ was reported, the optimized cell in this work shows an improvement of $16.30 \%$ in efficiency. Aside the alkali Post Deposition Treatment (PDT) done on CIGS absorbers which were used in the experimental solar cells referred to in Table 8 their efficiencies could be improved upon by carefully controlling the concentration of multivalent defect in their absorbers as this form of defect is prevalent in chalcopyrite materials.

Table 7. Optimized parameters of the device.

\begin{tabular}{lcc}
\hline Optimized Parameters & Absorber & Buffer \\
\hline Thickness $(\mu \mathrm{m})$ & 1.2 & 0.01 \\
Multivalent defect density $\left(\mathrm{cm}^{3}\right)$ & $10^{10}$ & - \\
\hline
\end{tabular}



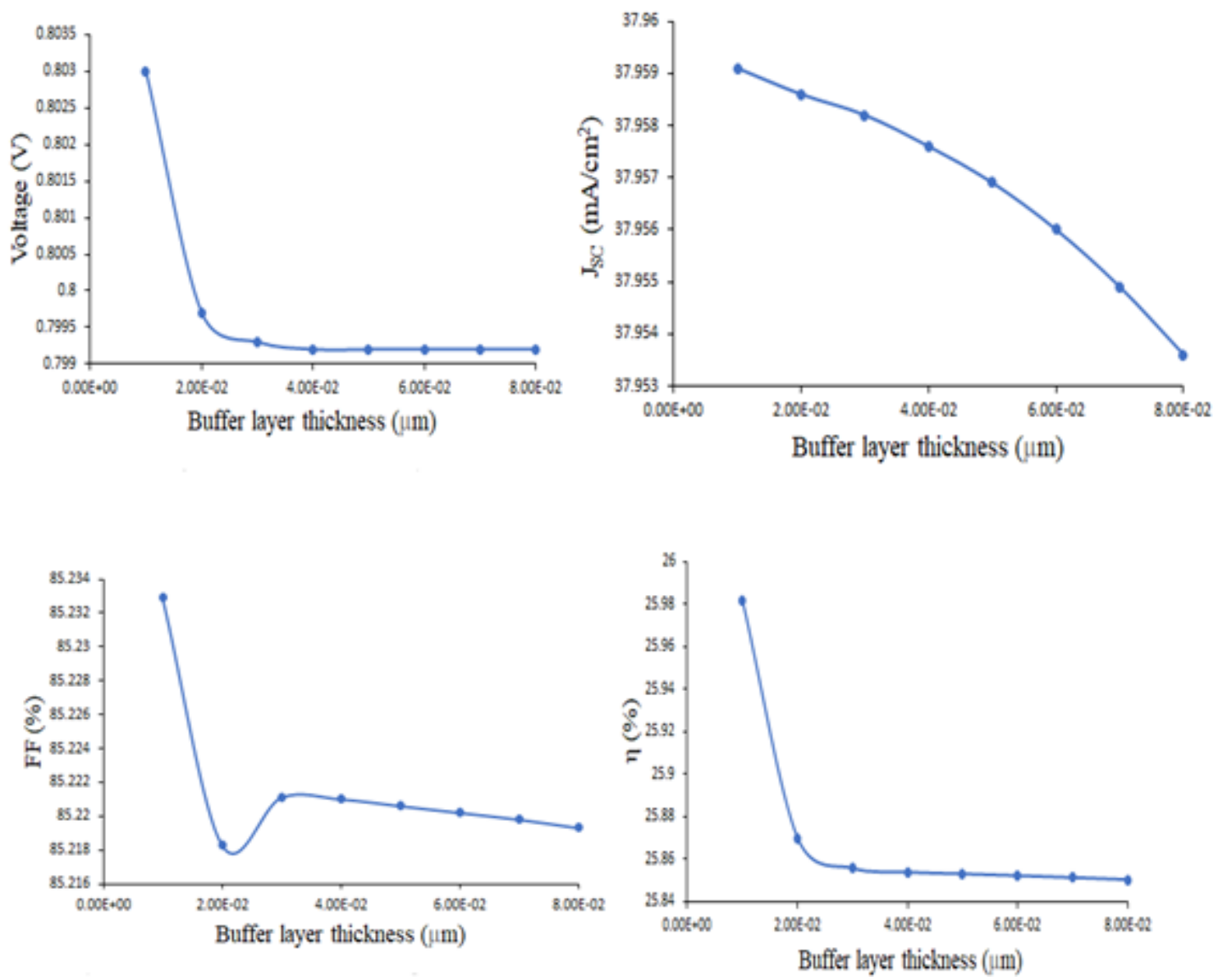

Figure 10. Variation in performance of CIGS solar cell with buffer layer thickness.

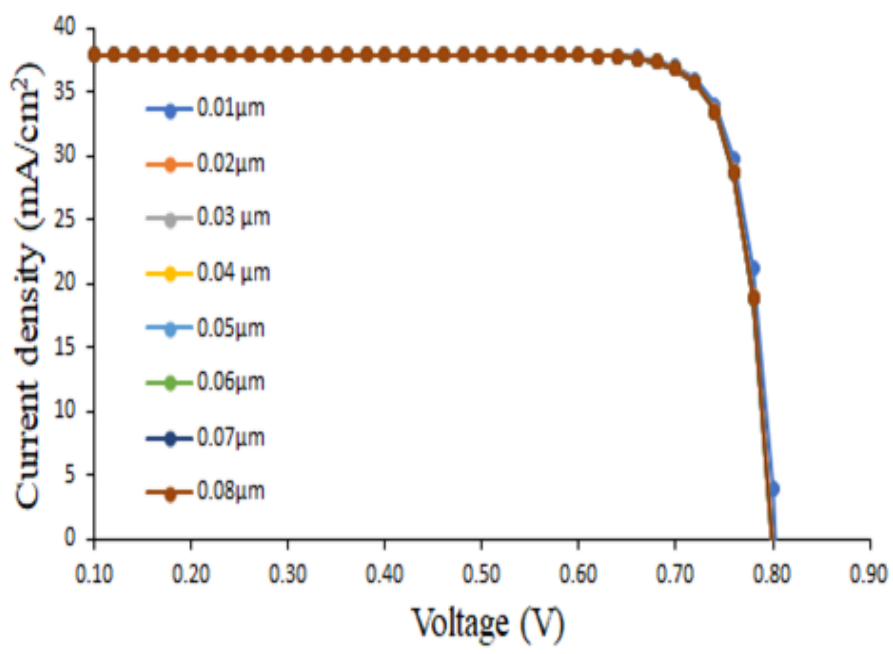

Figure 11. J-V curves of CIGS solar cells with various values of buffer layer thickness.

\section{Conclusion}

In this work, we undertook numerical simulation to investigate multivalent defects and the influence of absorber layer thickness and buffer layer thickness on $\mathrm{Al}|\mathrm{ZnO}: \mathrm{Al}| \mathrm{In}_{2} \mathrm{~S}_{3} \mid \mathrm{CIGS}$

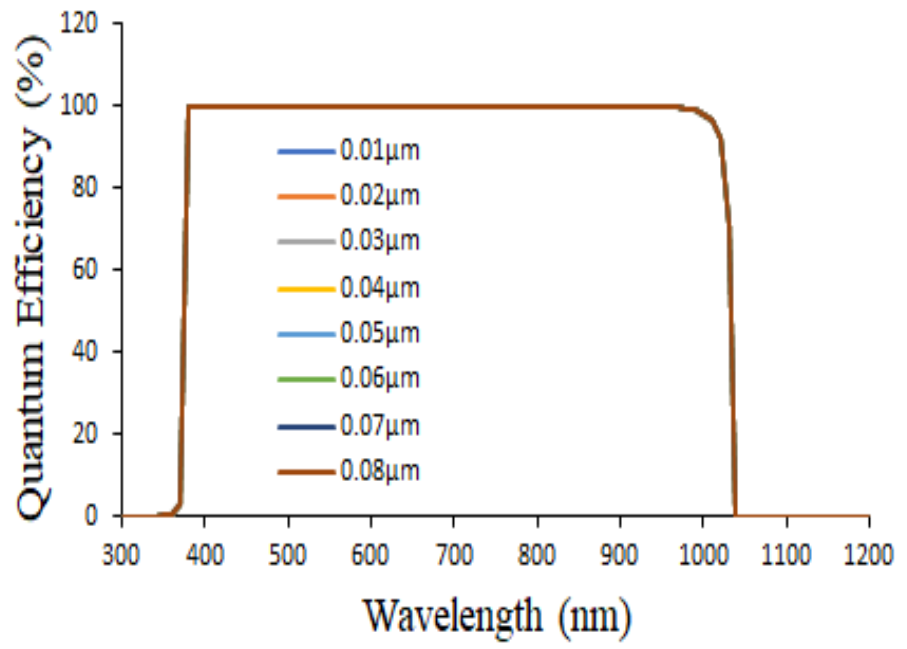

Figure 12. Quantum efficiency as a function of wavelength for different values of buffer $\left(\operatorname{In}_{2} S_{3}\right)$ layer thickness.

$|P t|$ structured solar cells using SCAPS code. The efficiency of the initial device which was found to be $25.85 \%$ with a multivalent defect density of $10^{14} \mathrm{~cm}^{-3}$ experienced a boost to 27 $\%$ when the solar cell was optimized with an absorber layer thickness of $1.2 \mu \mathrm{m}$, buffer layer thickness of $0.01 \mu \mathrm{m}$ and a 

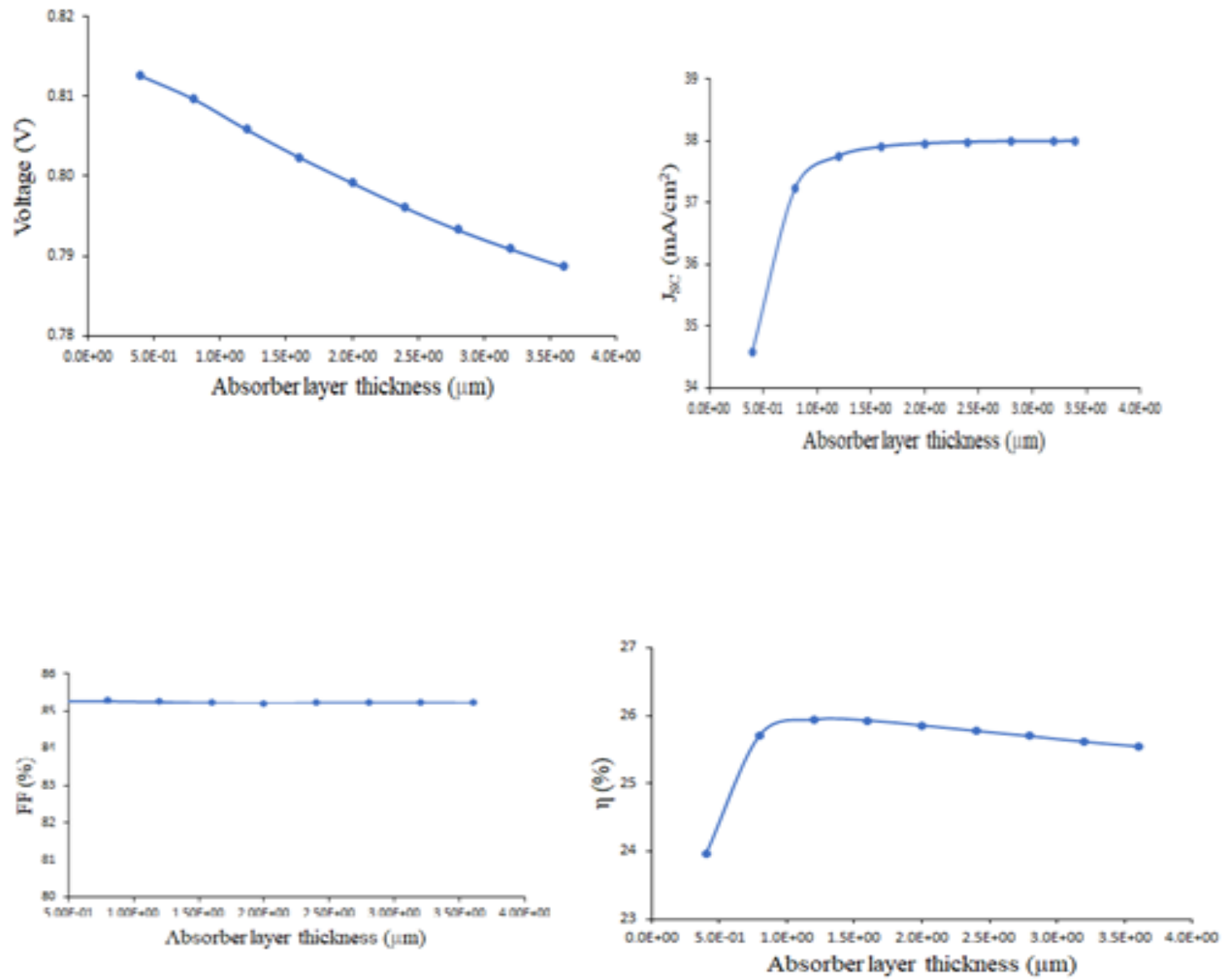

Figure 13. Variation in performance of CIGS solar cells with absorber layer thickness.

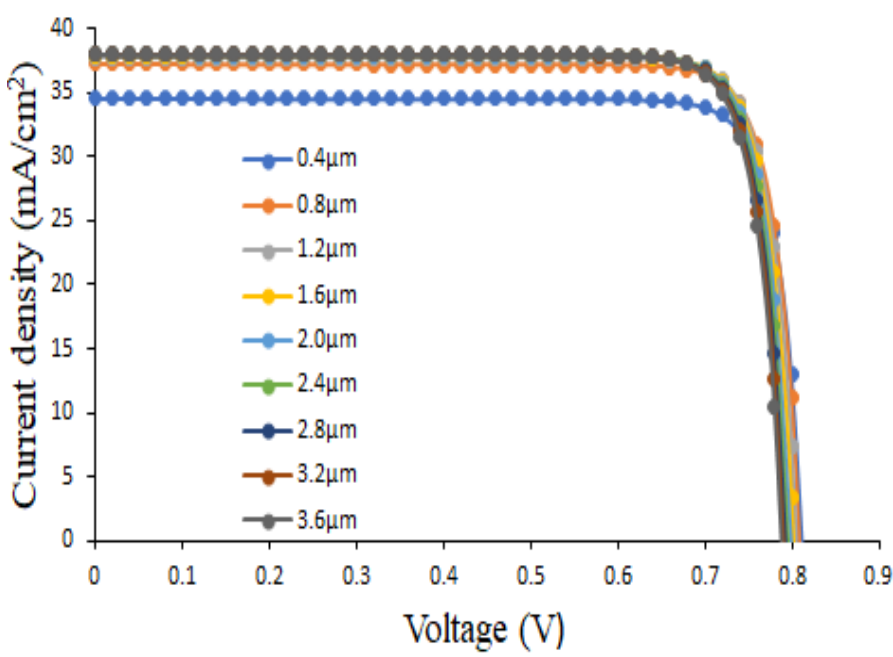

Figure 14. J-V curves of CIGS solar cell with various values of absorber layer thickness.

multivalent defect density of $10^{10} \mathrm{~cm}^{-3}$ in the CIGS absorber layer. The results obtained revealed that when the density of multivalent defect in the absorber was varied from $10^{10} \mathrm{~cm}^{-3}$ through $10^{17} \mathrm{~cm}^{-3}$, the efficiency of the CIGS photovoltaic cells dropped from $26.81 \%$ to $16.87 \%$ representing a decrease of

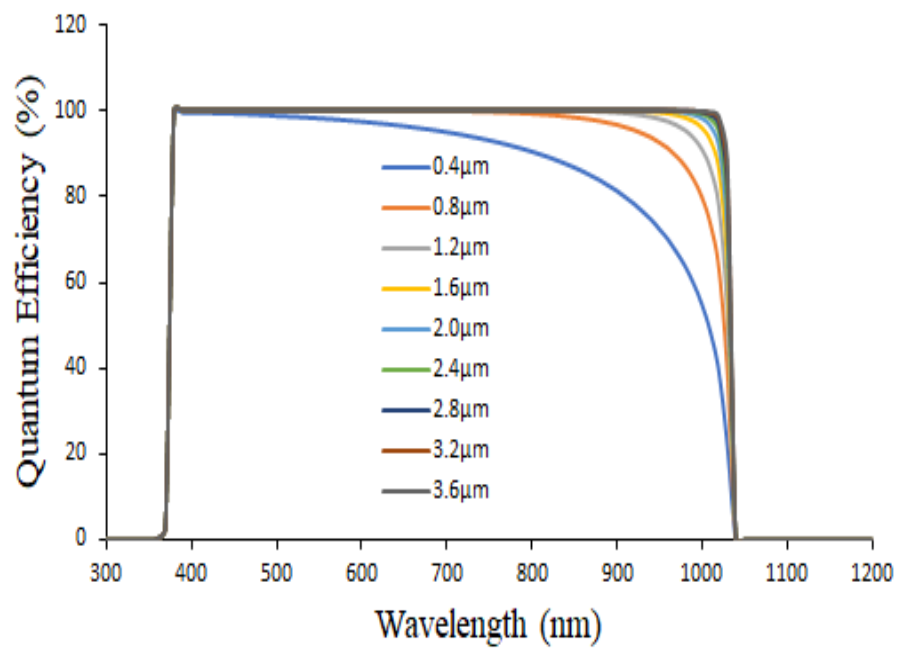

Figure 15. Quantum efficiency as a function of wavelength for different values of absorber (CIGS) layer thickness.

$58.92 \%$. This result clearly shows how detrimentally multivalent defects can affect the performance of CIGS solar cells. As expected, increasing the absorber layer thickness caused an increase in efficiency until an optimal thickness of $1.2 \mu \mathrm{m}$ was achieved while increase in buffer layer thickness from $0.01 \mu \mathrm{m}$ 
Table 8. Photovoltaic parameters corresponding to optimized parameters of the CIGS solar cells compared with those of experimental researches.

\begin{tabular}{lcccc}
\hline Simulation & $\begin{array}{c}\mathbf{V}_{\mathbf{O C}} \\
(\mathbf{V})\end{array}$ & $\begin{array}{c}\mathbf{J}_{\mathbf{s c}} \\
\left(\mathbf{m A} \mathbf{A} / \mathbf{c m}^{2}\right)\end{array}$ & $\begin{array}{c}\mathbf{F F} \\
\mathbf{\%}\end{array}$ & $\begin{array}{c}\eta \\
\mathbf{\%}\end{array}$ \\
\hline Initial & 0.7992 & 37.9576 & 85.2200 & 25.8500 \\
Optimized absorber layer thickness $(\mu \mathrm{m})$ & 0.8059 & 37.7506 & 85.2655 & 25.9403 \\
Optimized buffer layer thickness $(\mu \mathrm{m})$ & 0.8030 & 37.9591 & 85.2329 & 25.9813 \\
Optimized multivalent defect density $\left(\mathrm{cm}^{3}\right)$ & 0.8209 & 37.9630 & 86.0388 & 26.8116 \\
Final Optimization & 0.8290 & 37.7541 & 86.2600 & 27.0000 \\
Experimental data & 0.7570 & 34.8000 & 79.1000 & $20.8000[31]$ \\
Experimental data & 0.7440 & 36.7000 & 80.5000 & $22.0000[32]$ \\
Experimental data & 0.7410 & 37.8000 & 80.6000 & $22.6000[18]$ \\
\hline
\end{tabular}

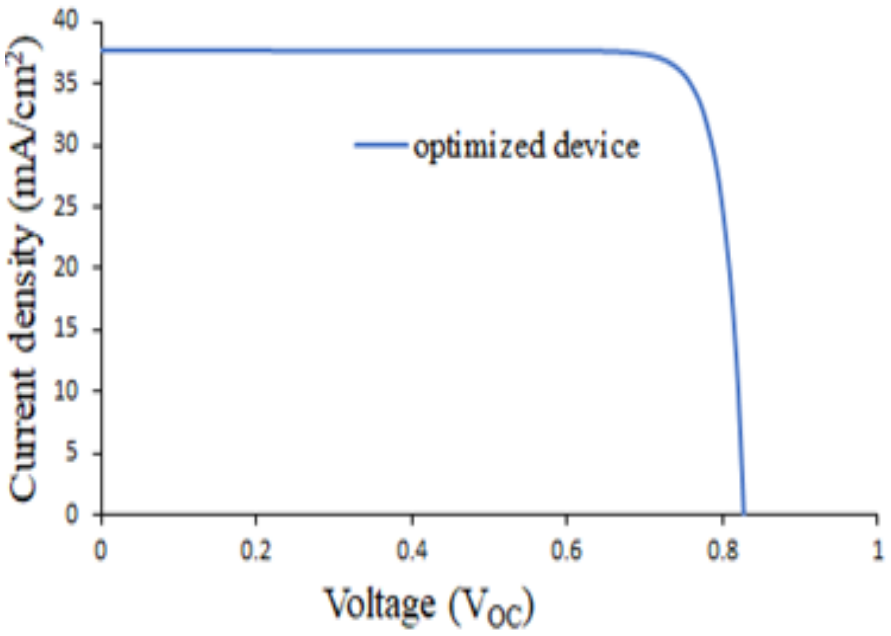

Figure 16. J-V curve of CIGS solar cell with optimized parameters.

through $0.08 \mu m$ caused a slight decrease of $0.51 \%$ in efficiency.

\section{Acknowledgments}

The authors wish to express their gratitude to Prof. Marc Burgelman and his colleagues at the University of Gent for providing SCAPS-1D software which was used in this work. We also thank the referees for the positive enlightening comments and suggestions, which have greatly helped us in making improvements to this paper.

\section{References}

[1] M. Hasan, M. Islam \& A. Khan, "Comprehensive analysis of $\mathrm{CdS} / \operatorname{In}_{2} \mathrm{~S}_{3} / \mathrm{ZnS}$ buffer layers on performance of CIGS solar cell", (Bachelor's Degree project, Military institute of science and technology, Bangladesh (2017).

[2] P. Lynn, "Electricity from sunlight: An introduction to photovoltaics", John Wiley and sons (2010).

[3] A. Hamanche, "Study of the type inversion of the semiconductor in irradiated solar cells", Doctoral Dissertation, Mohamed Khider University, Democratic and popular republic of Algeria (2018).

[4] K. Biswas, S. Lany \& A. Zunger, "The consequences of multivalent elements in inorganic solar absorber: Multivalency of Sn in Cu2ZnSnS4". Applied physics letters, 96 (2010) 201902. http://dx.doi.org/10.1063/1.3427433.
[5] S. Banerjee, Y. Ojha, K. Vikas \& A. Kumar, "High efficient CIGS based thin film solar cell performance optimization using PCID", International research journal of Engineering and technology (IRJET), 3 (2016).

[6] M. Mathew, "Engineering the properties of Indium Sulphide for thin film solar cells by doping" (Doctoral dissertation). Cochin University of Science and Technology, India, (2009).

[7] S. Ouedraogo, F. Zougmore, \& J. Ndjaka, "Numerical analysis of CopperIndium-Gallium-Diselenide based solar cells by SCAPS".International Journal of photoenergy, (2013). http://dx.doi.org/10.1155/2013/421076.

[8] A. Adekoya, A. Alabi, \& A. Oni, "Performance of CIGS solar cell with changes in Absorber layer thickness and back contacts", CARD international journal of science and advanced innovative research (IJSAIR), 2 (2017).

[9] A. Niemegeers, S. Gillis \& M. Burgleman, "A user program for realistic simulation of polycrystalline heterojunction solar cells; SCAPS-1D", Proceedings of the 2 nd world conference on photovoltaic energy conversion, Wein (1998).

[10] N. Khoshsirat, \& N. Yunus, "Copper- Indium- Gallium- Diselenide (CIGS) nanocrystalline bulk semiconductor as the absorber layer and its current technological trend and optimization", (2016), http://dx.doi.org/10.5772/64166.

[11] J. Keller, M. Knipper, J. Parisi, I. Riedel, T. Dalibor \& A. Avellan, "Impact of thickness variation of the $\mathrm{ZnO}$ : $\mathrm{Al}$ window layer on optoelectronic properties of CIGSSe solar cells". Mater. Res. Soc. Symp. Proc 1324 (2011), http://dx.doi.org/10.1557/opl.2011.1058.

[12] A. Kotbi, B. Hartiti, A. Batan, S. Fadili, A. Ridah \& P. Thevanin, "The effect of several parameters on the performance of CuInS2 - based solar cells using SCAPS-1D software", Journal of fundamental and applied science, (2019), http://dx.doi.org/10.4314/jfas.v11i2.11.

[13] R. Scheer \& H. Schock, "Chalcopyrite photovoltaics: physics, technologies and thin film devices". Wiley- $\mathrm{VCH},(2011)$.

[14] M. Ali, M. Hossain, M. Biswas, K. Alam \& M. Khan, "Numerical simulation and observation the characteristics of CIGS thin film solar cells using SCAPS-1D”. American Journal of Engineering Research (AJER), 7 (2018), pp176-182.

[15] M. Soce, M. Dieng, K. Ehemba, D. Diallo \& I. Wade, "Influence of doping of the absorber and the charged defects on the electrical performance of CIGS solar cells". International Journal of scientific and research publications, 5 (2015).

[16] W. Haynes, "CRC handbook of chemistry and physics (97th ed)". New York: CRC press, (2017).

[17] S. Wei, S. Zhang \& A. Zunger, "Effects of Ga addition to CuInSe2on its electronic, structural and defect properties", Applied Physics letters, 72 (1998) pp3199-3201.

[18] P. Jackson, R. Wuerz, D. Hariskos, E. Lotter, W. Witte \& M. Powalla, "Effects of heavy alkali elements in $\mathrm{Cu}$ (In, Ga) Se2 solar cell with efficiencies up to $22.6 \%$ ", Physica Status Solidi (RRL) (2016), http://dx.doi.org/10.1002/pssr.201600199.

[19] S. Dabbabi, T. Nasr \& N. Kamoun-Turki, "Parameters optimization of CIGS solar cell using 2D physical modeling". Results in physics, (2017), https://doi.org/10.1016/j.rinp.2017.06.057.

[20] Y. Khattak, "Modelling of high-power conversion efficiency thin film solar cells" (Doctoral Dissertation), Universitat Politecaica de Valencia, (2019). 
[21] T. Duc, "Electronic properties of intrinsic defects and impurities in GaN". (Doctoral Dissertation), Linkoping University, Sweden, (2015).

[22] S. Sienbentritt \& U. Rau, "Wide gap chalcopyrites", Springer - verlag, Berlin Heidelberg, (2006).

[23] ] S. Zhang, S. Wei \& A. Zunger, "Stabilization of energy compounds via ordered arrays of defect pairs", Physical review letters 78 (1997).

[24] M. Wanda, S. Ouedrago, F. Tchoffo, F. Zougmore \& J. Ndjaka, "Numerical investigation and analysis of $\mathrm{Cu} 2 \mathrm{ZnSnS} 4$ based solar cells by SCAPS-1D", International Journal of Photoenergy, (2019), https://doi.org/10.1155/2016/2152018.

[25] S. Oyedele, B. Soucase \& B. Aka, "Numerical simulation and performance optimization of $\mathrm{Cu}$ (In, Ga) Se2 solar cells", IOSR Journal of applied physics (JOSR-JAP), 18 (2016) pp1-11.

[26] J. Gray, "The physics of the solar cell". In A. Luque \& S. Hegedus (Eds), Handbook of photovoltaic science and engineering, John wiley and sons, (2003).

[27] A. Chadel, B. Benyoucef, \& M. Chadel, "A comparative study of CIGS solar cells based on $\mathrm{Zn}(\mathrm{O}, \mathrm{S})$ buffer layers and CIGS solar cells based on
CdS buffer layers", Optoelectronics and advanced materials- rapid communications, 9 (2015) pp653-656.

[28] A. Benmir \& M. Aida, "Analytical modelling and simulation of CIGS solar cells", Energy procedia, 36 (2013) pp618-627, https://doi.org/10.1016/j.egypro.2013.07.071.

[29] M. Hossain, P. Chelvanathan, M. Zaman, M. Karim, M. Alghoul \& N. Amin, "Prospects of Indium Sulphide as an Alternative to Cadmium Sulphide Buffer Layer in CIS Based Solar Cells From Numerical Analysis", Chalcogenide Letters, 8 (2011).

[30] P. Jackson, D. Hariskos, R. Wuerz, W. Wischmann \& M. Powalla, "Compositional investigation of potassium doped $\mathrm{Cu}$ (In, Ga) Se2solar cells with efficiencies up to $20.8 \%$ ”, Physica Status Solidi (RRL), 8 (2014), https://doi.org/10.1002/pssr.201409040.

[31] ZWS, "Thin film photovoltaics success story continues: ZWS sets European record of 22 percent for CIGS cells", https :

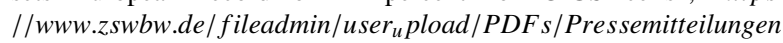
/2016/pi07 - 2016-ZSW - CIGS 22Percent-en.pdf, (2016). 